\title{
The Effects of pH-Neutral Electrolysed Oxidising Water on Growth and Development of Chrysanthemums
}

\author{
Andrej ŠUŠEK*, Klara COPOT, Metka ŠIŠKO \\ University of Maribor, Faculty of Agriculture and Life Sciences, Pivola 10, 2311 Hoče, Slovenia
}

\begin{abstract}
The aim of the study was to analyse the effects of $\mathrm{pH}$-neutral electrolysed oxidising water (pH-neutral EOW), prepared by using the Envirolyte ${ }^{\circledast}$ system, on the growth and development of chrysanthemums. The experiment included two varieties of potted ('Tonka Blanc', 'Jahou CoCo') and two cut flower varieties of chrysanthemums ('Annecy White', 'Ninja'). The test plants planted in pots were irrigated with three different solutions of $\mathrm{pH}$-neutral EOW $(0 \%, 0.1 \%$ and $0.2 \%)$. Based on the results of the study, we can confirm that $\mathrm{pH}$-neutral EOW has a significant effect on the growth and development of the studied chrysanthemum varieties. In potted chrysanthemums, we found a significant effect on the increased number and diameter of inflorescences, as well as fresh and dried weight of the plant and inflorescences. Chrysanthemums for cut flowers were taller and more developed, with a greater weight of the aboveground part of the plant. Its effect on the growth and development of the studied varieties depended on the solution of the mixture. Best results were observed with the $0.2 \%$ solution of $\mathrm{pH}$-neutral EOW.
\end{abstract}

Key words: electrolysed oxidising water, chrysanthemums, Dendranthema $\times$ grandiflora Tzvelv., growth, morphological characteristics

\section{INTRODUCTION}

Chrysanthemums are one of the most important cultivated ornamental plants in the world, sold as plants for cut flowers, potted plants and as perennials. They are popular because of their wide range of shapes and sizes of flowers, brilliance of colour tones, long lasting florets, and relative ease of cultivation throughout the year. In commercial production, two groups of plants are grown, both for cut flowers and as potted plants (Anderson, 2007; Boodley and Newman, 2009; Dole and Wilkins, 2005).

Water is essential for growing chrysanthemums. The plants need plenty of water to produce high quality flowers. The quality of water is important for irrigating plants as it has an impact on the growth and development of the plant and its health. Parameters that affect water quality are $\mathrm{pH}$, salinity, toxicity of certain ions, alkalinity and hardness, microbiological purity, etc. However, many diseases can occur during the development of chrysanthemum, especially in high soil and air humidity and inadequate ventilation during cultivation in greenhouses (Dole and Wilkins, 2005).

Surface water (rivers, streams, canals, water catchments, artificial lakes, reservoirs, ponds, dams), groundwater (boreholes, wells), rainwater, tap water and treated wastewater are used for irrigation. To remove harmful microorganisms from water, chemicals (such as chlorine, ozone, peracetic acid or hydrogen peroxide) or processes such as UV irradiation and membrane filtration are used (Chen et al., 2017; Dandie et al., 2019; Hai et al., 2014; Mahajan et al., 2014; Markland et al., 2017; Martínez et al., 2011).

Many authors report of advantages of using electrolysed oxidising water (EOW), which is generated through the

${ }^{*}$ Correspondence to:

E-mail:andrej.susek@um.si 
electrolysis of chloride-containing water (generally in the form of sodium or potassium chloride) to form hypochlorous acid and reactive oxygen species $\left(\cdot \mathrm{OH}, \mathrm{O}_{3}, \mathrm{H}_{2} \mathrm{O}_{2}\right)$ that are toxic to micro-organisms (Jeong et al., 2007; Jeong et al., 2009; Rahman et al., 2016; Ogunniyi et al., 2019; Ogunniyi et al., 2021). The various types of EOW described in literature include acidic EOW ( $\mathrm{pH} 2-3.5$ ), slightly acidic EOW ( $\mathrm{pH}$ 5-6.5), alkaline EOW ( $\mathrm{pH} \mathrm{10-13),} \mathrm{slightly} \mathrm{alkaline} \mathrm{EOW}$ (pH 8-10), and neutral EOW (pH 7-8) (Rahman et al., 2016). Neutral EOW is used as a disinfectant in soaking and washing fresh vegetables (Abadias et al., 2008) or fruit (Torlak, 2014) and in the seafood (Khazandi et al., 2017) and meat industries (Han et al., 2018; Veasey and Muriana, 2016). It can also be used to mist greenhouses, sterilise equipment and soil, and as an additive to irrigation water. The use of sodium-based salts rather than potassium for generation of the EOW might be of concern in the context of plant production because of the potential problems associated with sodium accumulation in soil, in contrast to the potential benefit of potassium supplementation for crop growth.

Published studies have demonstrated the efficacy of EOW as a disinfectant in the production of vegetables, fruit, seafood and meat. However, there has been no report on its efficacy on plant growth. In this preliminary study, we investigated the effects of neutral EOW in the form of potassium chloride on the growth and development of chrysanthemums. We assume that by disinfecting the irrigation water and adding potassium, the growth of the plants and their resistance to pathogens is improved.

\section{MATERIAL AND METHODS}

\section{Plant material}

Two varieties of chrysanthemums for cut flowers ('Annecy White' and 'Ninja') and two varieties of potted chrysanthemums ('Jahou CoCo' and 'Tonka Blanc') were included in the experiment conducted in a greenhouse. All varieties have a reaction time of eight weeks. The variety 'Annecy White' is characterised by branched growth and several inflorescences on one stem ('spray' form). The variety 'Ninja' can be grown as a standard variety with one inflorescence per stem or as a branched variety. The variety 'Jahou CoCo' is characterised by the formation of a large number of bright yellow inflorescences, up to $5 \mathrm{~cm}$ in diameter, and is categorised in the multiflora group of potted chrysanthemums, growing to a height of $25 \mathrm{~cm}$. The variety 'Tonka Blanc' is used for growing in pots and belongs to group of multiflora chrysanthemums that grow up to $25 \mathrm{~cm}$ in height.

\section{Substrate, planting and fertilisation}

For planting, the substrate Einheits Erde (type ED $73+$ Eisen $+\mathrm{pH}$ ) produced by the German company (Einheitserde Werkverband e.V) was used, which is intended for cultivation of pot plants and structural plants. The main components of the substrate are white peat and clay. At planting, $140 \mathrm{~g}$ of slow-release fertiliser (5-6 months) Osmocote ${ }^{\circledast}$ was added to $70 \mathrm{l}$ of substrate, with the $\mathrm{NPK}+\mathrm{Mg}$ nutrient content in the ratio $17: 9: 11(2)(\mathrm{w} / \mathrm{w} / \mathrm{w} / \mathrm{w})$ with micro nutrients. Chrysanthemums for cut flowers were planted in pots with a diameter of $12 \mathrm{~cm}$, and potted chrysanthemums in pots with a diameter of $14 \mathrm{~cm}$. Each pot was used for a single plant. When plants transitioned to the flowering stage, we used the Ferty 4 fertiliser at each watering (every 2 to 3 days), with the $\mathrm{NPK}+\mathrm{Mg}$ nutrient content in the ratio of $8: 16: 24(4)(\mathrm{w} / \mathrm{w} /$ $\mathrm{w} / \mathrm{w})$ with micro nutrients in $0.1 \%$ solution. Per treatment, 26 plants were planted. The experiment was laid out in three replicates using a random block system. A total of 312 plants were included in the experiment.

\section{Electrolysed oxidising water}

A pH-neutral EOW was produced using the Envirolyte ${ }^{\circledast}$ system (Envirolyte Industries International Ltd.). We used the ANK Neutral Anolyte solution, in the form of potassium chloride $(\mathrm{KCl})$, with a $\mathrm{pH}$ of 7 , active chlorine content of 500 $\mathrm{mg} / \mathrm{l}$, and a redox potential of $700 \mathrm{mV}$. The effect of ANKNeutral Anolyte was studied for $0 \%$ (tap water), $0.1 \%$ and $0.2 \%$ solutions. Plants were irrigated by hand, with an irrigation shower, using a dispenser to dose the exact concentration of $\mathrm{pH}$-neutral EOW. The plants were irrigated 63 times from planting until evaluation.

\section{Measurements}

Evaluation of morphological characteristics of potted chrysanthemums was carried out at two specific time points: in the stage of inflorescence bud formation and in the flower opening stage. Chrysanthemums for cut flowers were evaluated only in the flower bud formation stage. At each evaluation date, 13 plants were selected from each treatment randomly. During the first evaluation (in the stage of inflorescence bud formation), we evaluated the following characteristics: plant height $(\mathrm{cm})$, plant width $(\mathrm{cm})$, plant circumference $(\mathrm{cm})$, number of shoots, fresh weight of aboveground part of plant $(\mathrm{g})$ and dry weight of aboveground part of plant (\%) (dried for 48 hours at $50{ }^{\circ} \mathrm{C}$ ). During the second evaluation, we evaluated the following characteristics of potted chrysanthemums: number of open and closed inflorescences, average circumference of three most open inflorescences $(\mathrm{cm})$, fresh weight of aboveground part of plant (g), dry weight of aboveground part of plant (\%) (dried for 48 hours at $50{ }^{\circ} \mathrm{C}$ ), fresh weight of inflorescences (g) and dry weight of inflorescences (\%) (dried for 48 hours at $\left.50{ }^{\circ} \mathrm{C}\right)$.

\section{Data analysis}

Data obtained in the experiment were statistically analysed using the statistical programme IBM SPSS Statistics Data Editor (Version 24). The analysis of variance (ANOVA) 
was performed for individual analysed morphological characteristics. Significances of differences between means at $\mathrm{P} \leq 0.05$ were tested using the Duncan method.

\section{RESULTS}

\section{The effects of pH-neutral EOW on morpho- logical characteristics of selected varieties of potted chrysanthemums}

In the inflorescence bud formation stage (first evaluation period), the studied plant characteristics in both varieties irrigated with $\mathrm{pH}$-neutral EOW differed significantly from those of control plants (Table 1). In the variety 'Tonka Blanc', we found that the plants irrigated with the $0.2 \%$ solution of pH-neutral EOW were significantly higher $(\bar{x}=18 \mathrm{~cm})$ and wider $(\bar{x}=18.1 \mathrm{~cm})$ than control plants and plants irrigated with the $0.1 \%$ solution. Plants irrigated with the $0.1 \%$ solution were also significantly higher $(\bar{x}=16.2 \mathrm{~cm})$ and wider $(\bar{x}=16.4 \mathrm{~cm})$ than control plants $(\mathrm{h}=14.1 \mathrm{~cm}, \mathrm{w}=14.4$ $\mathrm{cm}$ ). Characteristics related to plant size, number of shoots, fresh weight of aboveground part of plant (FWAGP) and dry weight of aboveground part of plant (DWAGP) were significantly higher in plants irrigated with $\mathrm{pH}$-neutral EOW than in control plants.

In the variety 'Jahou CoCo', we found that plants irrigated with the $0.2 \%$ solution of $\mathrm{pH}$-neutral EOW differed significantly from control plants and from plants irrigated with $0.1 \%$ solution. They were higher $(\bar{x}=21.9 \mathrm{~cm})$, had a greater circumference, were more branched, and had higher fresh and dry weight. Plant width differed significantly only compared to control plants. Plants irrigated with the $0.1 \%$ solution were also significantly higher $(\bar{x}=19.3 \mathrm{~cm})$, wider $(\bar{x}=29.2 \mathrm{~cm})$, had a greater circumference, more shoots, and higher fresh weight than control plants $(\mathrm{h}=16.7 \mathrm{~cm})$.

In the second evaluation period, conducted in the flower opening stage, the studied morphological characteristics of plants in both varieties irrigated with $\mathrm{pH}$-neutral EOW also differed significantly from those of control plants (Table 2). In the variety 'Tonka Blanc', we found that the plants irrigated with the $0.2 \%$ solution of $\mathrm{pH}$-neutral EOW developed significantly larger flowers $(\bar{x}=5.1 \mathrm{~cm})$ than control plants $(\bar{x}=4.5 \mathrm{~cm})$ and plants irrigated with the $0.1 \%$ solution $(\bar{x}=4.8 \mathrm{~cm})$. Values for characteristics related to fresh weight of aboveground part of plant (FWAGP), dry weight of aboveground part of plant (DWAGP), fresh weight inflorescences (FWINF) and dry weight of inflorescences (DWINF) were significantly higher in plants irrigated with $\mathrm{pH}$-neutral EOW than in control plants.

In the variety 'Jahou CoCo', we found that plants irrigated with $\mathrm{pH}$-neutral EOW formed significantly more inflorescences and higher fresh weight of aboveground plant part (Table 2). Inflorescence diameter $(\bar{x}=4.8 \mathrm{~cm})$, dry weight of aboveground plant part $(\bar{x}=15.2 \%)$ and dry weight of inflorescence $(\bar{x}=14.1 \mathrm{~cm})$ were significantly higher when plants were irrigated with the $0.1 \%$ solution compared to control plants. When the plants were irrigated

Table 1: Average values of morphological characteristics of potted chrysanthemum varieties 'Tonka Blanc' and 'Jahou CoCo' in the inflorescence bud formation stage, depending on irrigating with $\mathrm{pH}$-neutral EOW

\begin{tabular}{|c|c|c|c|c|c|c|c|}
\hline Variety & SEOW $(\%)$ & $\mathrm{H}(\mathrm{cm})$ & $\mathrm{W}(\mathrm{cm})$ & $\mathrm{C}(\mathrm{cm})$ & NoS & $\begin{array}{c}\text { FWAGP }(\mathrm{g}) \\
\begin{array}{c}\text { DWAGP } \\
(\%)\end{array}\end{array}$ \\
\hline 'Tonka & 0 & $14.1 \mathrm{c}$ & $14.4 \mathrm{c}$ & $22.5 \mathrm{~b}$ & $14.7 \mathrm{~b}$ & $102.71 \mathrm{~b}$ & $16.1 \mathrm{~b}$ \\
\hline Blanc' & 0.1 & $16.2 \mathrm{~b}$ & $16.4 \mathrm{~b}$ & $25.3 \mathrm{a}$ & $18.4 \mathrm{a}$ & $128.43 \mathrm{a}$ & $22.2 \mathrm{a}$ \\
\hline & 0.2 & $18.0 \mathrm{a}$ & $18.1 \mathrm{a}$ & $24.4 \mathrm{a}$ & $18.5 \mathrm{a}$ & $143.07 \mathrm{a}$ & $20.4 \mathrm{a}$ \\
\hline 'Jahou & 0 & $16.7 \mathrm{c}$ & $24.5 \mathrm{~b}$ & $59.3 \mathrm{c}$ & $13.5 \mathrm{c}$ & $95.56 \mathrm{c}$ & $22.9 \mathrm{~b}$ \\
\hline CoCo' & 0.1 & $19.3 \mathrm{~b}$ & $29.2 \mathrm{a}$ & $67.9 \mathrm{~b}$ & $17.8 \mathrm{~b}$ & $129.98 \mathrm{~b}$ & $24.5 \mathrm{a}$ \\
\hline & 0.2 & $21.9 \mathrm{a}$ & $30.4 \mathrm{a}$ & $72.9 \mathrm{a}$ & $19.5 \mathrm{a}$ & $148.10 \mathrm{a}$ & $24.4 \mathrm{a}$ \\
\hline
\end{tabular}

SEOW - pH-neutral EOW solution (\%); H - plant height (cm); W - plant width (cm); C - plant circumference (cm); NoS - number of shoots (main and side); FWAGP - fresh weight of aboveground part of plant (g); DWAGP - dry weight of aboveground part of plant (\%); a, b, c - different characters represent statistically significant differences (Duncan, $\alpha-=0.05$ )

Table 2: Average values of morphological characteristics of potted chrysanthemum varieties 'Tonka Blanc' and 'Jahou CoCo' in the flower opening stage, depending on watering with $\mathrm{pH}$-neutral EOW

\begin{tabular}{|c|c|c|c|c|c|c|c|}
\hline Variety & SEOW $(\%)$ & NoINF & DiaINF $(\mathrm{cm})$ & FWAGP $(\mathrm{g})$ & DWAGP (\%) & FWINF (g) & DWINF (\%) \\
\hline 'Tonka & 0 & $241.7 \mathrm{a}$ & $4.5 \mathrm{c}$ & $211.21 \mathrm{~b}^{11}$ & $10.3 \mathrm{~b}$ & $96.33 \mathrm{~b}$ & $11.4 \mathrm{~b}$ \\
\hline Blanc' & 0.1 & $272.0 \mathrm{a}$ & $4.8 \mathrm{~b}$ & $266.48 \mathrm{a}$ & $11.3 \mathrm{a}$ & $133.36 \mathrm{a}$ & $11.9 \mathrm{a}$ \\
\hline & 0.2 & $277.0 \mathrm{a}$ & $5.1 \mathrm{a}$ & $274.07 \mathrm{a}$ & $11.0 \mathrm{a}$ & $115.54 \mathrm{a}$ & $13.4 \mathrm{a}$ \\
\hline 'Jahou & 0 & $137.4 \mathrm{~b}$ & $4.3 \mathrm{~b}$ & $156.99 \mathrm{~b}$ & $14.8 \mathrm{c}$ & $50.71 \mathrm{~b}$ & $12.3 \mathrm{c}$ \\
\hline CoCo' & 0.1 & $178.5 \mathrm{a}$ & $4.8 \mathrm{a}$ & $210.85 \mathrm{a}$ & $15.2 \mathrm{~b}$ & $72.24 \mathrm{~b}$ & $14.1 \mathrm{~b}$ \\
\hline & 0.2 & $189.3 \mathrm{a}$ & $4.5 \mathrm{ab}$ & $227.69 \mathrm{a}$ & $15.9 \mathrm{a}$ & $122.11 \mathrm{a}$ & $14.6 \mathrm{a}$ \\
\hline
\end{tabular}

SEOW - pH-neutral EOW solution (\%); NoINF - number of inflorescences; DiaINF - diameter of open inflorescences (cm); FWAGP - fresh weight of aboveground part of plant (g); DWAGP - dry weight of aboveground part of plant (\%); FWINF - fresh weight of inflorescences (g); DWINF - dry weight of inflorescences (\%); a, b, $c$ - different characters represent statistically significant differences (Duncan, $\alpha-=0.05$ ) 
Table 3: Average values of morphological characteristics of chrysanthemum varieties for cut flowers 'Annecy White' and 'Ninja' in the inflorescence bud formation stage, depending on watering with $\mathrm{pH}$-neutral EOW

\begin{tabular}{|c|c|c|c|c|c|c|c|}
\hline Variety & SEOW $(\%)$ & $\mathrm{H}(\mathrm{cm})$ & $\mathrm{W}(\mathrm{cm})$ & $\mathrm{C}(\mathrm{cm})$ & NoS & FWAGP $(\mathrm{g})$ & DWAGP $(\%)$ \\
\hline 'Annecy & 0 & $66.1 \mathrm{~b}$ & $7.4 \mathrm{~b}$ & $15.4 \mathrm{a}$ & $13.5 \mathrm{a}$ & $88.89 \mathrm{~b}$ & $19.2 \mathrm{~b}$ \\
\hline White' & 0.1 & $75.3 \mathrm{a}$ & $10.9 \mathrm{a}$ & $20.0 \mathrm{a}$ & $14.2 \mathrm{a}$ & $130.54 \mathrm{a}$ & $19.9 \mathrm{a}$ \\
\hline & 0.2 & $81.6 \mathrm{a}$ & $12.3 \mathrm{a}$ & $19.3 \mathrm{a}$ & $15.5 \mathrm{a}$ & $134.30 \mathrm{a}$ & $21.1 \mathrm{a}$ \\
\hline 'Ninja' & 0 & $78.8 \mathrm{c}$ & $11.5 \mathrm{a}$ & $7.9 \mathrm{~b}$ & $11.9 \mathrm{c}$ & $121.20 \mathrm{c}$ & $15.8 \mathrm{c}$ \\
\hline & 0.1 & $85.0 \mathrm{~b}$ & $8.3 \mathrm{~b}$ & $7.4 \mathrm{~b}$ & $15.5 \mathrm{~b}$ & $130.65 \mathrm{~b}$ & $17.5 \mathrm{~b}$ \\
\hline & 0.2 & $92.8 \mathrm{a}$ & $13.6 \mathrm{a}$ & $17.9 \mathrm{a}$ & $18.1 \mathrm{a}$ & $147.91 \mathrm{a}$ & $19.3 \mathrm{a}$ \\
\hline
\end{tabular}

SEOW - pH-neutral EOW solution (\%); H - plant height (cm); W - plant width (cm); C - plant circumference (cm); NoS - number of shoots; FWAGP - fresh weight of aboveground part of plant (g); DWAGP - dry weight of aboveground part of plant (\%); a, b, c - different characters represent statistically significant differences (Duncan, $\alpha-=0.05$ )

with the $0.2 \%$ solution, they had significantly higher dry weight of aboveground plant part $(\bar{x}=15.9 \%)$, dry weight of inflorescences $(\bar{x}=14.6 \%)$, and the fresh weight of inflorescences $(\bar{x}=122.1 \mathrm{~g})$ was also significantly higher compared to control plants and plants watered with $0.1 \%$ concentration.

\section{The effects of pH-neutral EOW on morpho- logical characteristics of selected varieties of chrysanthemums for cut flowers}

Chrysanthemums for cut flowers were evaluated only in the flower bud formation stage (Table 3). In the variety 'Annecy White', we found that plants irrigated with $\mathrm{pH}$-neutral EOW were significantly higher, wider, and formed significantly higher fresh weight and dry weight of the aboveground part of the plant.

In the variety 'Ninja', we found that plants irrigated with the $0.2 \%$ solution of $\mathrm{pH}$-neutral EOW differed significantly from control plants and plants irrigated with $0.1 \%$ solution in all studied morphological characteristics. Plants irrigated with the $0.1 \%$ solution were also significantly higher $(\bar{x}=$ $85 \mathrm{~cm})$, wither $(\bar{x}=8.3 \mathrm{~cm})$, had more shoots $(\bar{x}=15.5)$, higher fresh weight $(\bar{x}=130.65 \mathrm{~g})$, and dry weight $(\bar{x}=17.5$ $\%)$, of aboveground plant parts than those watered with tap water.

\section{DISCUSSION}

Based on the results obtained in the evaluation of morphological characteristics of potted chrysanthemums and chrysanthemums for cut flowers, we can conclude that $\mathrm{pH}$-neutral EOW had a great effect on plant growth and development in all considered varieties and that no harmful effects on plants were found.

Plant habit, fresh weight of aboveground part of plant and dry weight of aboveground part of plant increased significantly at the flower bud formation stage. We also found that both varieties for cut flowers, when irrigated with $\mathrm{pH}$-neutral EOW, had a significantly higher habit at the flower bud formation stage and consequently a significantly higher fresh and dry weight of aboveground part of plant compared to control plants. The growth and development of studied chrysanthemum varieties also depended on the EOW solution used. In the chrysanthemum for cut flowers, the morphological characteristics of the variety 'Ninja', when irrigated with the $0.2 \%$ solution of $\mathrm{pH}$-neutral EOW, differed significantly from plants watered with the $0.1 \%$ solution. No significant differences were found in the variety 'Annecy White', but a trend of increasing studied morphological characteristics was observed when using the $0.2 \%$ solution of $\mathrm{pH}$-neutral EOW. Also, in potted chrysanthemum varieties, the best results were observed with the $0.2 \%$ solution of $\mathrm{pH}$ neutral EOW.

We can assume that plant growth and development was affected by the use of $\mathrm{pH}$-neutral EOW in the form of potassium chloride $(\mathrm{KCl})$. The use of potassium-based salts might have potential benefit of potassium supplementation for crop growth. Potassium is required in large quantities for optimum plant growth and productivity (Oosterhuis et al., 2014) since it is essential for completion of various physiological and metabolic functions: maintains cell growth and turgor pressure (Anschütz et al., 2014), hydraulic conductance (Oddo et al., 2011), leaf expansion (JordanMeille and Pellerin, 2004), photosynthesis (Pasandi Pour et al., 2021), root elongation (Song et al., 2018), transport of photoassimilates between source and sink organs $(\mathrm{Hu}$ etal., 2017), and regulation of stomatal guard cells (Raschke, 1975).

Plant tissue analysis reflects the level of nutritional status of the plant. Particularly, a combination of soil and tissue analyses may provide a better understanding of the role of potassium in the use of $\mathrm{pH}$-neutral EOW in the form of potassium chloride $(\mathrm{KCl})$. As the effects of EOW as a disinfectant in the production of vegetables, fruits, seafood and meat are already established, the impact on pathogenic microorganisms occurring in irrigation water, soil and on chrysanthemum plants should be studied further.

\section{CONCLUSION}

The $\mathrm{pH}$-neutral electrolysed oxidising water ( $\mathrm{pH}$-neutral EOW) prepared using the Envirolyte ${ }^{\oplus}$ system significantly affects the growth and development of the studied chrysanthemum varieties. Its effect depended on the solution of the mixture and varieties. 


\section{REFERENCES}

1. Abadias, M., Usall, J., Oliveira, M., Alegre, I., \& Viñas, I. (2008). Efficacy of neutral electrolyzed water (NEW) for reducing microbial contamination on minimallyprocessed vegetables. International Journal of Food Microbiology, 123(1-2), 151-158. Retrieved from: doi:10.1016/j.ijfoodmicro.2007.12.008

2. Anderson, N. O. (Ed.). (2006). Flower breeding and genetics: issues, challenges and opportunities for the 21st century. Springer Science \& Business Media.

3. Anschütz, U., Becker, D., \& Shabala, S. (2014). Going beyond nutrition: regulation of potassium homoeostasis as a common denominator of plant adaptive responses to environment. Journal of Plant Physiology, 171(9), 670687. Retrieved from: DOI: 10.1016/j.jplph.2014.01.009

4. Boodley, J. W., \& Newman, S. E. (2009). The commercial greenhouse. Clifton Park, NY: Delmar Cengage Learning.

5. Chen, J., Loeb, S., \& Kim, J.-H. (2017). LED revolution: fundamentals and prospects for UV disinfection applications. Environmental Science: Water Research \& Technology, 3(2), 188-202. Retrieved from: https://doi. org/10.1039/C6EW00241B

6. Dole, J. M., \& Wilkins, H. F. (2005). Floriculture: principles and species. Upper Saddle River, N.J.: Pearson/ Prentice Hall.

7. Dandie, C. E., Ogunniyi, A. D., Ferro, S., Hall, B., Drigo, B., Chow, C. W. K., Venter, H., Myers, B., Deo, P., Donner, E., \& Lombi, E. (2020). Disinfection options for irrigation water: Reducing the risk of fresh produce contamination with human pathogens. Critical Reviews in Environmental Science and Technology, 50(20), 21442174. Retrieved from: https://doi.org/10.1080/10643389 .2019 .1704172

8. Hai, F. I., Riley, T., Shawkat, S., Magram, S. F., \& Yamamoto, K. (2014). Removal of pathogens by membrane bioreactors: A review of the mechanisms, influencing factors and reduction in chemical disinfectant dosing. Water, i(12), 3603-3630. Retrieved from Retrieved from: https://doi.org/10.3390/w6123603

9. Han, D., Hung, Y.-C., \& Wang, L. (2018). Evaluation of the antimicrobial efficacy of neutral electrolyzed water on pork products and the formation of viable but nonculturable (VBNC) pathogens. Food Microbiology, 73, 227-236. Retrieved from: https://doi.org/10.1016/j. fm.2018.01.023

10. Hu, W., Coomer, T. D., Loka, D. A., Oosterhuis, D. M., \& Zhou, Z. (2017). Potassium deficiency affects the carbon-nitrogen balance in cotton leaves. Plant Physiology and Biochemistry, 115, 408-417. Retrieved from: DOI: 10.1016/j.plaphy.2017.04.005

11. Jeong, J., Kim, C., \& Yoon, J. (2009). The effect of electrode material on the generation of oxidants and microbial inactivation in the electrochemical disinfection processes. Water Research, 43(4), 895-901. Retrieved from: https://doi.org/10.1016/j.watres.2008.11.033

12. Jeong, J., Kim, J. Y., Cho, M., Choi, W., \& Yoon, J. (2007). Inactivation of Escherichia coli in the electrochemical disinfection process using a $\mathrm{Pt}$ anode. Chemosphere,
67(4), 652-659. Retrieved from: https://doi.org/10.1016/j. chemosphere.2006.11.035

13. Jordan-Meille, L., \& Pellerin, S. (2004). Leaf area establishment of a maize (Zea Mays L.) field crop under potassium deficiency. Plant and Soil, 265(1), 75-92. Retrieved from: https://link.springer.com/article/10.1007/ s11104-005-0695-Z

14. Oosterhuis, D. M., Loka, D. A., Kawakami, E. M., \& Pettigrew, W. T. (2014). The physiology of potassium in crop production. In D. L. Sparks (Ed.), Advances in Agronomy (pp. 203-233). Academic Press.

15. Khazandi, M., Deo, P., Ferro, S., Venter, H., Pi, H., Crabb, S., Amorico, T., Ogunniyi, A. D., \& Trott, D. J. (2017). Efficacy evaluation of a new water sanitizer for increasing the shelf life of Southern Australian King George Whiting and Tasmanian Atlantic Salmon fillets. Food Microbiology, 68, 51-60. Retrieved from: https://doi.org/10.1016/j. fm.2017.06.008

16. Mahajan, P. V., Caleb, O. J., Singh, Z., Watkins, C. B., \& Geyer, M. (2014). Postharvest treatments of fresh produce. Philosophical Transactions of the Royal Society A: Mathematical, Physical and Engineering Sciences, 372, 20130309. Retrieved from: https://doi.org/10.1098/ rsta.2013.0309

17. Markland, S. M., Ingram, D., Kniel, K. E., \& Sharma, M. (2017). Water for agriculture: the convergence of sustainability and safety. Microbiology Spectrum, 5(3). Retrieved from: https://doi.org/10.1128/microbiolspec. PFS-0014-2016

18. Martínez, S. B., Pérez-Parra, J., \& Suay, R. (2011). Use of ozone in wastewater treatment to produce water suitable for irrigation. Water Resources Management, 25(9), 21092124. Retrieved from: https://doi.org/10.1007/s11269011-9798-X

19. Oddo, E., Inzerillo, S., La Bella, F., Grisafi, F., Salleo, S., \& Nardini, A. (2011). Short-term effects of potassium fertilization on the hydraulic conductance of Laurus nobilis L. Tree Physiology, 31(2), 131-138. Retrieved from: DOI: $10.1093 /$ treephys/tpq115

20. Ogunniyi, A. D., Dandie, C. E., Ferro, S., Hall, B., Drigo, B., Brunetti, G., Venter, H., Myers, B., Deo, P., Donner, E., \& Lombi, E. (2019). Comparative antibacterial activities of neutral electrolyzed oxidizing water and other chlorinebased sanitizers. Scientific Reports, 9(1), 19955. Retrieved from: DOI: 10.1038/s41598-019-56248-7

21. Ogunniyi, A. D., Tenzin, S., Ferro, S., Venter, H., Pi, H., Amorico, T., Deo, P., \& Trott, D. J. (2021). A pHneutral electrolyzed oxidizing water significantly reduces microbial contamination of fresh spinach leaves. Food Microbiology, 93, 103614. Retrieved from: DOI: 10.1016/j. fm.2020.103614

22. Pasandi Pour, A., Farahbakhsh, H., \& Tohidinejad, E. (2021). Nitrogen, phosphorous and potassium levels affected growth indices, leaf gas exchange parameters and biomass production of henna (Lawsonia inermis L.) ecotypes. Industrial Crops and Products, 163, 113297. Retrieved from: DOI: 10.1016/j.indcrop.2021.113297

23. Rahman, S., Khan, I., \& Oh, D.-H. (2016). Electrolyzed water as a novel sanitizer in the food industry: Current trends and future perspectives. Comprehensive Reviews in 
Food Science and Food Safety, 15(3), 471-490. Retrieved from: https://doi.org/10.1111/1541-4337.12200

24. Raschke, K. (1975). Simultaneous requirement of carbon dioxide and abscisic acid for stomatal closing in Xanthium strumarium L. Planta, 125(3), 243-259. Retrieved from: https://www.jstor.org/ stable/23371809?seq=1\#metadata_info_tab_contents

25. Song, W., Xue, R., Song, Y., Bi, Y., Liang, Z., Meng, L., Meng, L., Dong, C., Wang, C., Liu, G., Dong, J., \& Zhang, Y. (2018). Differential response of first-order lateral root elongation to low potassium involves nitric oxide in two tobacco cultivars. Journal of Plant Growth Regulation, 37(1), 114-127. Retrieved from: DOI: 10.1007/s00344017-9711-9

26. Torlak, E. (2014). Inactivation of Alicyclobacillus acidoterrestris spores in aqueous suspension and on apples by neutral electrolyzed water. International Journal of Food Microbiology, 185, 69-72. Retrieved from: https://doi.org/10.1016/j.ijfoodmicro.2014.05.022

27. Veasey, S., \& Muriana, P. M. (2016). Evaluation of electrolytically-generated hypochlorous acid ('electrolyzed water') for sanitation of meat and meatcontact surfaces. Foods, 5(2). Retrieved from: https:// doi.org/10.3390/foods5020042 


\section{Vpliv pH-nevtralne elektrolizirane vode na rast in razvoj krizantem}

\section{IZVLEČEK}

Namen raziskave je bil proučiti vpliv pH-nevtralne elektrolizirane vode ( $\mathrm{pH}$ nevtralne EV), ki smo jo pridobivali s sistemom Envirolyte ${ }^{\circledast}$, na rast in razvoj krizantem. V poskus smo vključili dve sorti lončnih krizantem ('Tonka Blanc', 'Jahou CoCo') in dve sorti krizantem za rezanje ('Annecy White', 'Ninja'). Rastline, posajene v lonce, smo po potrebi zalivali s tremi različnimi koncentracijami pH nevtralne $\mathrm{EV}(0 \%, 0,1 \%$ in $0,2 \%)$. Na osnovi rezultatov raziskave lahko potrdimo, da ima pH nevtralna EV značilen vpliv na rast in razvoj proučevanih sort krizantem. Pri lončnih krizantemah smo ugotovili značilen vpliv na povečano število in premer socvetij ter svežo maso in suho snov rastline in socvetij. Krizanteme za rezanje so višje in bolj razraščene ter imajo večjo maso nadzemnega dela rastline. Vpliv pH nevtralne EV na rast in razvoj proučevanih sort je odvisen od koncentracije raztopine. Najboljše rezultate smo dosegli z uporabo $0,2 \%$ koncentracije.

Ključne besede: elektrolizirana voda, krizanteme, Dendranthema $\times$ grandiflora Tzvelv., rast, morfološke lastnosti 